\title{
Sphingosine-1-Phosphate Lyase 1
}

National Cancer Institute

\section{Source}

National Cancer Institute. Sphingosine-1-Phosphate Lyase 1. NCI Thesaurus. Code C105033.

Sphing osine-1-phosphate lyase 1 (568 aa, $64 \mathrm{kDa}$ ) is encoded by the human SGPL1 gene. This protein plays a role in apoptosis, the elevation of stress-induced ceramide production, and the metabolism of phosphorylated sphing oid bases. 